Jurnal PG-PAUD Trunojoyo : Jurnal Pendidikan dan Pembelajaran Anak Usia Dini, Volume 7, Nomor 1, April 2020, hal 52-58, ISSN : 2528-3553 (online), ISSN: 2407-4454 (print)

\title{
PENINGKATAN HASIL BELAJAR MATEMATIKA MELALUI MEDIA REALIA PADA SISWA KELAS 2 SD
}

\author{
Annisa Herlida Sari \\ Program Studi Pendidikan Islam Anak Usia Dini, Institut Agama Islam Negeri Metro Lampung \\ email: annisaherlidasari@ymail.com
}

Received (Bulan Februari 2020), Accepted (Bulan Maret 2020), Published (Bulan April 2020)

\begin{abstract}
The Enhancement of Mathematics Learning Outcomes through Realia Media in Student Grade 2 in Elementary School. The aim of this research is to improve the results of learning math students second grade through the application of media realia. The research was implemented on SDN 1 Kalianda, South Lampung. This study used class action research conducted through two cycles, a cycle of comprising planning, action, observation and reflection. The subject of research is a whole number of second grade student SDN 1 Kalianda having the mathematical value helpdown KKM totaled 12 student. Analysis of the percentage data used in this study was based on an agreement with a researcher and collaborator is using percentage increase reched $71 \%$ atthe end of the cycle. Analysis of data obtained from the result of percentage increase at the end of the cycle reached $84,33 \%$. The end result of a whole analysis percentage data is an inrease more than $71 \%$. Based on an increase in the percentage of this research, all student have reached percentage inrease reahed $71 \%$, the can be expressed that hypotesis accepted. It could be concluded that the use of the media realia can enchange the results of learning math student second grade of elementary school student.
\end{abstract}

Keywords: media, realia, mathematics

\begin{abstract}
Abstrak: Peningkatan Hasil Belajar Matematika melalui Media Realia pada Siswa Kelas 2 SD. Tujuan dari penelitian ini adalah meningkatkan hasil belajar matematika siswa kelas 2 Sekolah Dasar melalui pelibatan media realia dalam pembelajaran. Penelitian ini dilakukan di SDN 1 Kalianda Lampung Selatan. Penelitian ini merupakan penelitian tindakan kelas yang dilakukan melalui dua siklus yang terdiri dari perencanaan (planning), tindakan (acting), pengamatan (observing), da refleksi (reflecting). Subjek penelitian adalah siswa kelas 2 SDN 1 Kalianda yang memiliki nilai matematika dibawah KKM, berjumlah 12 siswa. Analisis persentase data berdasarkan kesepakatan peneliti dan kolabolator adalah dengan menggunakan persentase kenaikan diakhir siklus mencapai $71 \%$. Analisis data diperoleh dari hasil persentase kenaikan diakhir siklus mencapai $84,33 \%$. Hasil akhir dari keseluruhan analisis persentase data adalah peningkatan mencapai lebih dari $71 \%$. Berdasarkan peningkatan persentase dari penelitian ini, semua siswa telah mencapai persentase kenaikan mencapai $71 \%$, maka dapat dinyatakan bahwa hipotesis diterima. Oleh sebab itu, disimpulkan bahwa penggunaan media dapat meningkatkan hasil belajar matematika siswa kelas 2 SD
\end{abstract}

Kata Kunci : media, realia, matematika 


\section{PENDAHULUAN}

Matematika menjadi salah satu ilmu dasar yang telah berkembang pesat dalam kehidupan manusia. Seperti yang telah diketahui, dalam kehidupan sehari-hari manusia tidak jauh dari persoalan matematika. Matematika bukan hanya sekedar perhitungan atau rumus-rumus melainkan suatu kebutuhan dalam kehidupan sehari-hari. Dalam kehidupan manusia baik langsung maupun tidak langsung selalu menggunakan matematika dalam kegiatannya.

Berdasarkan survei yang telah dilakukan oleh PISA (Programme of International Student Assesment) pada tahun 2009 pada tes komprehensif dengan mengukur kemampuan matematika, Indonesia berada pada posisi ke 61 dari 65 negara peserta. (http://Padepokanguru.Org/2011/12/11/SurveiInternasional-Pisa/). Di era milenial seperti saat ini, setiap negara dituntut untuk menyesuaikan diri dengan perkembangan matematika yang ada. Oleh sebab itu, maka mau tidak mau matematika sangat penting untuk diajarkan sejak dini untuk mempersipkan generasi cerdas yang siap menghadapi tantangan zaman.

Fakta-fakta yang terjadi di lapangan bersumber pada pengamatan yang dilakukan oleh peneliti di kelas 2 SD Negeri 1 Kalianda Lampung Selatan menunjukkan bahwal belajar matematika siswa belum optimal. Masih terdapat siswa yang belum mencapai hasil belajar diatas Kriteria Ketuntasan Minimal (KKM). Siswa juga masih kesulitan ketika menjawab pertanyaan dari guru. Masih banyak siswa yang belum memahami informasi yang disampaikan oleh guru, hal ini juga dapat dilihat dari kemampuan siswa dalam menjawab soal yang diberikan. Berdasarkan pengamatan dan wawancara dengan siswa dan walikelas, rendahnya hasil belajar siswa juga disebabkan masih banyaknya guru yang belum menyediakan pembelajaran yang beragam. Pembelajaran berlangsung dengan menggunakan papan tulis dan buku modul. Selain itu, pembelajaran terpusat pada guru, sehingga siswa kurang berinteraksi dengan guru. Pengetahuan yang didapat siswa bukan dibangun sendiri, karena siswa jarang menemukan jawaban sendiri atas permasalahan maupun konsep yang dipelajari. Pengetahuan diberikan secara langsung oleh guru. Pembelajaran yang konvensional dan monoton mengakibatkan siswa cenderung cepat merasa jenuh dalam mengikuti pembelajaran.

Cara berpikir anak pada rentang usia kelas 2 Sekolah Dasar masih dalam masa peralihan dari konkrit menuju abstrak, anak belum mampu sepenuhnya berpikir secara abstrak. Anak dalam usia ini masih perlu benda-benda konkret untuk memahami sesuatu terutama pelajaran matematika. Anak pada rentang usia kelas 2 SD akan lebih mudah memahami pelajaran yang dilihatnya secara nyata dan mudah dipahami dalam kegiatan yang dilakukannya sehari-hari.

Media realia adalah sumber belajar yang berasal dari benda-benda yang dekat dengan siswa, sehingga siswa merasa familiar dengan media yang digunakan selama proses pembelajaran. Banyak hal atau benda yang dapat dipilih, dikembangkan, dan dimanfaatkan sebagai media realia dalam proses pembelajaran matematika.

Media realia yang berasal dari bendabenda konkrit dapat meningkatkan minat belajar matematika, dengan melibatkan pengalaman nyata siswa. Pembelajaran yang menarik minat siswa dipengaruhi oleh kreativitas guru dalam memilih sumber belajar. Media realia mampu melibatkan seluruh indra siswa, baik penglihatan, pendengaran gerak dan hati siswa dalam proses pembelajaran juga sangat mempengaruhi proses pembelajaran yang menarik dan berkesan bagi siswa. Hal ini tentunya akan memudahkan siswa untuk mencapai hasil belajar matematika yang baik serta mengaplikasikan hasil belajarnya dalam kehidupan sehari-hari.

Penelitian dimaksudkan untuk meningkatkan hasil belajar matematika pada siswa kelas 2 SD melalui pelibatan media realia di SDN 1 Kalianda, Lampung Selatan. Hasil belajar yang diharapkan adalah hasil belajar siswa dalam menjawab soal dengan tepat. Materi pembelajaran hasil belajar matematika dalam penelitian ini dibatasi pada materi operasi perkalian yang hasilnya adlaah bilangan dengan dua angka dan operasi pembagian bilangan dengan dua angka.

\section{Hasil Belajar Matematika}

Hasil belajar merupakan hasil yang diperoleh dari individu setelah melalui proses belajar. Hasil belajar dapat nampak dari adanya perubahan perilaku pada diri seseorang. Seperti yang dikatakan Winkel, bahwa hasil 
belajar adalah perubahan yang menjadikan individu berubah dalam sikap serta tingkah lakunya (Purwanto, 2010). Perubahan tingkah laku didapat setelah melakukan pelatihanpelatihan atau berdasarkan pengalaman yang telah dialami oleh seseorang.

Hasil belajar didefinisikan sebagai sebuah perubahan yang terjadi pada diri individu melalui proses pembelajaran. Perubahan yang dimaksud tidak hanya pada pengetahuan melainkan juga keterampilan dan tingkah laku. Perubahan yang terjadi diharapkan tidak hanya terjadi didalam kelas, melainkan juga dapat diterapkan dalam kehidupan nyata. Hasil belajar tersebut dapat dilihat dari tiga aspek yaitu aspek kognitif, aspek afektif, serta aspek psikomotor.

Matematika bukan hanya dibatasi pada perhitungan, melainkan lebih menitik beratkan pada pemahaman seseorang. Mathematics, as defined by modernity, is to be understood neither as sum of representational and calculatory devices; nor as a simple system like logic. (Ernest, 1996). Pendapat ini dapat diartikan secara bebas, bahwa matematika haruslah dipahami bukan hanya sekedar jumlah dan perhitungan, atau dapat juga dikatakan bahwa matematika sebagai sistem yang sederhana seperti logika. Berdasarkan pendapat tersebut dapat dikatakan bahwa matematika tidak hanya terkurung atau dibatasi oleh perhitungan atau angka-angka saja, melainkan lebih dari itu matematika juga harus dipahami.

Matematika menekankan pada penalaran seseorang, bagaimana seseorang mampu menelaah suatu masalah serta mencari pemecahan masalah dari masalah tersebut. Pre $K$ mathematics is much more than rote memorization of counting words or names of shapes. Children of this age are capable of engaging in thoughtful mathematics reasoning and problem-solving. (The Albert Shanker Institute Preschool Curriculum: What's, 2000). Pendapat ini dapat diartikan bahwa matematika lebih dari mengahafal dan menghitung kata atau bentuk-bentuk, anak usia dini sudah mampu melakukan penalaran maematika untuk melakukan pemecahan masalah atau problem solving. Berdasarkan pendapat tersebut, dapat diungkapkan bahwa matematika untuk anak usia dini tidak hanya sebatas menghafal atau menghitung, melainkan anak sudah mampu untuk melakukan pemecahan masalah yang sesuai dengan tahapan perkembangannya menggunakan penalaran matematika.

Operasi hitung perkalian dan pembagian dijadukan sebagai konsep dasar dalam pembelajaran matematika pada kelas 2 Sekolah Dasar. Perkalian merupakan operasi matematika penskalaan satu bilangan dengan bilangan lain. (http://id.wikipedia.org/wiki/Perkalian).

Penskalaan satu bilangan dengan bilangan lainnya dapat diartikan sebagai penjumlahan yang berulang. Hal ini dikarenakan didalam operasi perkalian, setiap faktor menghasilkan produk.

Perkalian yang dimaksud dalam penelitian ini ialah perkalia dasar, yaitu perkalian yang hasilnya bilangan dua angka ialah, perkalian yang faktornya menghasilkan produk dua angka. Contohnya pada perkalian $3 \times 4$, maka hasilnya ialah 12 yang merupakan bilangan dua angka. Pada perkalian 5 x 5 hasilnya ialah 25,25 juga merupakan bilangan dua angka. Maka Pada penelitian ini, perkalian yang dmaksud ialah perkalian satu angka dengan satu angka yang menghasilkan bilangan dua angka, seperti contoh diatas.

Operasi hitung pembagian juga dikatakan sebagai lawan dari operasi hitung perkalian. Seperti yang diungkapkan oleh Heruman, yang menyatakan bahwa pembagian ialah lawan dari perkalian, yaitu pengurangan yang berulang. (Heruman, 2007). Operasi pembagian ialah pengurangan yang berulang sampai habis.

Pembagian juga didefinisikan sebagai pengurangan berulang bilangan yang sama. (Rosida, 2004). Penanaman konsep pembagian pengurangan berulang ini misalnya $6: 2=3$, artinya 6 dikurangi 2 sampa habis maka di dapat sebanyak 3 kali $(6-2-2-2=0)$, untuk sampai pada hasil bilangan nol memerlukan 3 kali pengurangan bilangan 2, hasil 6:2 =3. Hal ini memperjelas konsep bahwa pembagian sebagai pengurangan berulang. Oleh karena itu, kemampuan prasyarat yang harus dimiliki siswa sebelum mempelajari pembagian adalah penguasaan pengurangan.

Hasil belajar matematika diartikan sebagai perubahan pada siswa setelah melalui proses belajar matematika. Setelah seorang siswa mengikuti proses pembelajaran matematika, maka siswa tersebut akan mendapat hasil belajar. Hasil belajar matematika adalah tingkat penguasaan dan perubahan kemampuan siswa setelah melewati 
proses pembelajaran matematika sesuai dengan tahapan usianya seperti yang tertera dalam standar kompetensi dan kompetensi dasar. Adanya perubahan sebagai hasil belajar matematika dapat dilihat dari aspek kognitif yang berhubungan dengan kemampuan ingatan, pemahaman, penerapan (aplikasi), analisis, sintesis, dan evaluasi yang dapat digunakan untuk menyelesaikan permasalahan sehari-hari yang didalamnya memerlukan penerapan pembelajaran matematika.

\section{Karakteristik Siswa Kelas 2 SD (7-8 tahun)}

Selain bimbingan dan stimulasi dari orang dewasa, yang juga perlu diketahui oleh orang dewasa ialah bahwa siswa usia kelas 2 SD masih memerlukan benda-benda konkret dalam pembelajrannya. Siswa kelas 2 SD masih membutuhkan benda-benda konkret karena siswa pada usia ini tahapan berpikrinya masih belum mampu untuk menelaah hal-hal yang abstrak. Pada aspek perkembangan kognitif, Piaget menjelaskan bahwa pikiran anak usia sekolah dasar kelas awal berada pada tahapan operasional konkret (concrete operational thought) (Desmita, 2005). Pada tahap ini, aktivitas berpikir anak difokuskan pada benda-benda dan peristiwa-peristiwa yang konkrit serta dapat diukur. Pada tahap ini siswa dapat berpikir lebih logis apabila dibandingkan dengan kemampuan sebelumnya. Berdasarkan penjelasan di atas, maka dapat disimpulkan bahwa pada tahap ini anak mampu menyelesaikan masalah dengan melibatkan benda-benda konkrit.

Selain beberapa pendapat yang telah disebutkan diatas, NCTM (National Council of Teacher Mthematics) juga membahas mengenai kemampuan yang harus dicapai oleh siswa sesuai dengan usianya. Prinsip dan standar pembelajaran matematika untuk anak usia dini menurut NCTM dijelaskan pada Tabel 1.

\section{Media Realia}

Media realia berupa benda nyata dapat dijadikan sebagai media pembelajaran yang efektif untuk memberikan media yang konkret pada anak. Uno menyatakan bahwa realia adalah benda konkrit yang dimanfaatkan sebagai bahan ajar (Hamzah, 2008). Berdasarkan pengertian tersebut, dapat dikatakan bahwa realia adalah media yang berasal dari benda nyata atau benda sebenarnya, yang dapat diperoleh dari benda- benda yang dekat dengan siswa serta dapat dijadikan media pembelajaran yang sesuai dengan proses pembelajaran.

\section{Tabel 1. Prinsip dan satndar pembelajaran matematika menurut NCTM (Sriningsih, 2008)}

\begin{tabular}{|c|c|}
\hline $\begin{array}{lr}\text { Program-program } & \\
\text { instruksional } & \text { dari } \\
\text { prasekolah } & \text { sampai } \\
\text { kelas } 2 & \text { harus } \\
\text { memungkinkan } & \text { semua } \\
\text { siswa untuk: } & \end{array}$ & $\begin{array}{l}\text { Harapan-harapan untuk kelas } \\
\text { prasekolah sampai kelas } 2 \\
\text { SD semua siswa prasekolah } \\
\text { hingga kelas } 2 \text { SD harus: }\end{array}$ \\
\hline $\begin{array}{l}\text { Memahami makna } \\
\text { operasi dan bagaimana } \\
\text { operasi itu saling } \\
\text { berhubungan. }\end{array}$ & 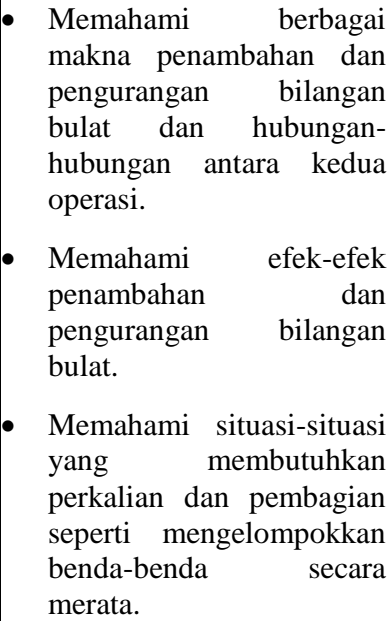 \\
\hline
\end{tabular}

Media realia tidak hanya berdiri sendiri, melainkan terdiri dari beberapa jenis. Menurut Sesls \& Glasglow, media realia terdiri dari model, specimen (contoh), manipulatif (peta, boneka). (Arsyad, 2004). Media realia yang dimaksudkan ialah penggunaan media realia yang tidak hanya digunakan dalam bentuk seutuhnya, melainkan juga ada beberapa cara yang termasuk media realia seperti, model, speciemen dan manipulatif.

Pemanfaatan media realia didalam kelas juga tidak terpaku pada pengadaan media reali didalam kelas. Uno menjelaskan bahwa media realia tidak selamanya harus dibawa ke dalam ruang kelas (Uno, 2008). Dengan demikian, media realia juga dapat dikunjungi atau dilihat dilingkungan sekitar tanpa perlu membawanya kedalam kelas. Hal ini tergantung pada kebutuhan pembelajaran.

Penggunaan media realia juga dapat dimodifikasi, agar dapat mempermudah pembelajaran dan pengadaan media. Pendapat ini juga dikuatkan oleh pendapat Heinich, yang menyatakan bahwa penggunaan realia 
juga dapat dimodifikasi, menurut Heinich, et. al modifikasi penggunaan realia dalam proses pembelajaran dapat dilakukan dengan tiga cara, yaitu: cutaway/ potongan, specimen/contoh, exhibit/pameran. (Uno, 2008). Penggunaan media realia tidak hanya pengadaan benda nyata secara utuh, melainkan juga dapat dimodifikasi.

Dalan penggunaannya media realia, guru perlu mempertimbangkan bentuk dan ukuran media yang sesuai dengan pembelajaran. Selain itu, guru hendaknya memberikan penjelasan yang singkat, karena siswa akan lebih konsentrasi kepada media realia. Media realia pun menjadi benar-benar digunakan dalam pembelajaran, tidak hanya sebatas pengisi waktu kosong pembelajaran. Guru juga perlu eksplor media realia supaya siswa sebanyak mungkin belajar melalui media realia serta gunakan peralatan lain yang dapat mendukung kegiatan pembelajaran. Langkah lainnya adalah guru perlu mengusahakan menggunakan satu jenis media realia, karena akan mengganggu konsentrasi belajar siswa; bila dibutuhkan media realia lain, maka usahakan media realia tersebut saling berhubungan.

\section{Pengembangan Konseptual Rancangan Tindakan}

Matematika merupakan ilmu yang menggunakan penalaran seseorang. Matematika berperan penting karena akan berpengaruh pada kehidupan siswa sehari-hari yang selalu melibatkan matematika. Banyak hal dalam kehidupan yang membutuhkan pemecahan masalah, matematika diharapkan dapat menstimulasi siswa dalam memecahkan masalah penalaran yang terjadi dalam kehidupan sehari-hari.

Siswa kelas 2 SD berada pada tahapan operasional konkret. Siswa masih membutuhkan benda-benda konkret untuk mempelajari sesuatu. Siswa belum mampu untuk berpikir secara abstrak. Untuk itu diperlukan penggunaan media pembelajaran yang dapat memudahkan siswa memahami pembelajaran yang disampaikan. Penggunaan media dimaksudkan agar siswa dapat memahami informasi yang abstrak menjadi lebih nyata. Salah satu bentuk media yang dapat digunakan oleh siswa ialah media realia.

Media realia merupakan benda nyata atau real, digunakan pada siswa kelas 2 SD karena pada masa ini siswa masih membutuhkan benda konkrit dalam pembelajaran. Siswa lebih mampu memahami pelajaran dengan adanya benda konkrit. Siswa dapat melihat langsung benda yang dimaksud dan digunakan selama proses pembelajaran matematika.

Media realia digunakan untuk meningkatkan hasil belajar matematika khususnya untuk memahami konsep matematika yang bersifat abstrak. Siswa memerlukan benda-benda konkrit atau rill dalam pembelajaran. Penggunaan media realia dalam pembelajaran matematika ini akan membantu anak dalam memahami dan menguasai materi yang sedang dipelajari, terutama pada materi perkalian dan pembagian bilangan dua angka khususnya dalam soal cerita. Pada materi perkalian dan bilangan dua angka khususnya dalam soal cerita, siswa lebih memahami perkalian dengan menggunakan benda asli, karena siswa mampu melihat dan menggunakan langsung media realia sehingga anak memehami apa yang dimaksud dalam soal.

Beberapa media realia yang dapat dimanfaatkan oleh guru antara lain: bendabenda yang mudah ditemukan di lingkungan sekolah, atau disekitar anak. Benda-benda nyata yang sesuai dan dapat digunakan dalam penyampaian materi pembelajaran atau sesuai dengan tema yang sedang berlangsung, yaitu pada subtema alat permainan dan peralatan sekolah. Melalui penggunaan benda nyata yang sudah sering dilihat oleh siswa, siswa akan lebih memahami pembelajaran yang disampaikan oleh guru. Melalui penggunaan media realia juga mampu membuat pembelajaran matematika memberikan pemahan yang mendalam pada siswa karena siswa dapat melihat langsung serta menggunakannya dalam proses pembelajaran.

Melalui penggunaan media realia maka pembelajaran matematika dapat disajikan dengan benda nyata sesuai dengan pembelajaran dan tema sehingga siswa dapat memahami materi pembelajaran. Berdasarkan deskripsi sebelumnya, maka pembelajaran matematika melalui media realia dapat meningkatkan hasil belajar matematika pada siswa kelas 2 di SDN 1 Kalianda, Lampung Selatan. Kompetensi belajar yang dioptimalkan ialah perkalian dan pembagian bilangan dua angka. 


\section{METODE}

Metode penelitian ini adalah penelitian tindakan (action research). Tujuan dari penelitian tindakan adalah untuk mengatasi suatu permasalahan yang terdapat di dalam kelas. Menurut McNiff (Arikunto, 2006) bahwa tujuan dari metode ini untuk melakukan perbaikan dan peningkatan layanan. Pada penelitian ini, peneliti sekaligus guru perlu melakukan sesuatu yang tujuannya telah ditentukan sebelumnya, yaitu untuk kemajuan siswa agar memiliki hasil belajar yang optimal.

Subjek yang terlibat adalah siswa kelas 2 SD di SDN 1 Kalianda. Subjek penelitian yang dipilih berdasarkan kriteria hasil belajar matematika siswa yang belum mencapai standar KKM. Jumlah subyek adalah 12 siswa, pemilihan siswa dilakukan pada pra penelitian melalui pengamatan selama pembelajaran serta merupakan hasil rekomendasi dari guru kelas.

Penelitian ini berlangsung di SDN 1 Kalianda Lampung Selatan yang beralamat di Jl. Veteran Atas no 143, RT.01/RW01. Kelurahan Kalianda, Kecamatan Kalianda, Lampung-Selatan. Adapun aktivitas pembelajaran anak di kelas 2 SD sedang dapat dikatakan efektif. Oleh sebab itu, penelitian dapat berlangsung.

Cara pengumpulan data dilakukan dengan cara non tes dan tes. Teknik non tes ini terdiri dari pengamatan/observasi, wawancara, dan dokumentasi terhadap kegiatan yang sedang berlangsung, sedangkan teknik tes menggunakan instrumen tes perbuatan.

Adapun data dalam penelitian tindakan ini adalah data kuantitatif dan kualitatif. Analisis data kuantitatif dilakukan secara berkesinambungan setiap siklus dengan persentasi kenaikan. Analisis data kualitatif dilakukan dengan cara menganalisis data dari hasil catatan lapangan, catatan wawancara dan catatan dokumentasi selama penelitian. Teknik analisis data yang digunakan bertujuan untuk mengetahui pengaruh penggunaan media realia terhadap peningkatan hasil belajar matematika siswa kelas $2 \mathrm{SD}$.

\section{HASIL PENELITIAN DAN PEMBAHASAN}

Deskripsi data kuantitatif mengenai hasil belajar matematika siswa kelas 2 SD melalui penggunaan media reala disajikan pada Tabel 2.

Tabel 2. Data Hasil Belajar Matematika Anak

\begin{tabular}{|l|c|c|c|}
\hline $\begin{array}{l}\text { Pra } \\
\text { Siklus }\end{array}$ & Siklus 1 & Siklus 2 & Peningkatan \\
\hline $48 \%$ & $64,83 \%$ & 82,33 & $34,33 \%$ \\
\hline
\end{tabular}

Berdasarkan hasil analisis data pada siklus 1, persentase kenaikan diperoleh sebesar $16,83 \%$ dan siklus 2 persentase kenaikan diperoleh sebesar 17,5\%. Jadi persentase kenaikan seluruhnya dari pra siklus hingga siklus 2 sebesar 34,33\%. Hal ini memiliki makna bahwa telah terjadi peningkatan persentase yang signifikan dari hasil belajar matematika siswa pada pra penelitiam hingga siklus 2 .

Hasil analisis data kualitatif menunjukkan bahwa penggunaan media realia dalam pembelajaran dapat mengoptimalkan hasil belajar matematika siswa pada materi perkalian dan pembagian bilangan dua angka. Selain itu, media realia juga dapat mendukung pemahaman anak mengenai tema yang akan dipelajari. Siswa menjadi lebih bersemangat dan antusias saat pembelajaran karena melibatkan benda yang sebenarnya, serta siswa menjadi terbiasa untuk bertanya dan mengungkapkan pendapatnya. Siswa dapat belajar dengan cara menemukan sendiri melalui kegiatan yang menyenangkan. Penggunaan media realia memudahkan siswa belajar menemukan sendiri serta terlibat secara aktif dalam proses pembelajaran. Siswa juga mendapatkan pengalaman baru dan berharga, sehingga rasa ingin tahu dan perhatian siswa pun dapat difasilitasi. Berdasarkan hasil pengamatan, melalui penggunaan media realia, siswa mampu menjawab dan menganalisis dengan tepat materi perkalian dan pembagian bilangan dua angka.

\section{SIMPULAN}

Persentase siklus 1 ke siklus 2 mengalami peningkatan pada indikator secara keseluruhan sebesar 17,5\%. Hal tersebut menunjukkan bahwa persentase kenaikan hasil belajar matematika anak dapat dikatakan signifikan karena terus meningkat. Dengan demikian, maka dapat dinyatakan bahwa melalui penggunaan media realia dapat meningkatkan hasil belajar matematika siswa kelas 2 SD di 
Jurnal PG-PAUD Trunojoyo : Jurnal Pendidikan dan Pembelajaran Anak Usia Dini, Volume 7, Nomor 1, April 2020, hal 52-58, ISSN : 2528-3553 (online), ISSN: 2407-4454 (print)

SDN 1 Kalianda. Setelah memperoleh persentase dengan kenaikan yang signifikan, maka penelitian dihentikan. Berdasarkan pemaparan tersebut, maka dapat disimpulkan bahwa pemberian tindakan berupa penggunaan media realia dapat meningkatkan hasil belajar matematika siswa kelas 2 SD di SDN 1 Kalianda.

Berdasarkan data kualitatif, terlihat adanya peningkatan hasil belajar matematika siswa kelas 2 SD melalui pemberian tindakan berupa penggunaan media realia. Penggunaan media realia disertai dengan tema yang berlangsung. Penggunaan media realia juga membuat anak belajar dengan menggunakan benda nyata sehingga anak lebih memahami pembelajaran. Berdasarkan hasil observasi dalam bentuk catatan lapangan dan catatan dokumentasi, dapat dilihat bahwa penggunaan media realia dapat meningkatkan hasil belajar matematika siswa kelas 2 SD di SDN 1 Kalianda.

\section{DAFTAR PUSTAKA}

Arikunto, Suharsimi, dkk., (2006). Penelitian Tindakan Kelas. Jakarta: Bumi Aksara

Arsyad, Azhar. (2004). Media Pembelajaran. Jakarta: Raja Grafindo Persada.

Desmita. (2005). Psikologi Perkembangan. Bandung : PT Remaja Rosdakarya.

Ernest, Paul. (1996). Mathematics, Education And Philosophy. An International Perspective. London: The Falmer Press

Hartati, Sofia. (2007). How To Be A Good Teacher And To Be A Good Mother. Jakarta: Enno Media.

Padepokan Guru Indonesia. (2011). Survey Internasional Pisa. Diakses dari (Http://Padepokanguru.Org/2011/12/11/Sur vei-Internasional-Pisa/)

Purwanto. (2010). Evaluasi Hasil Belajar. Yogyakarta: Pustaka Pelajar.

The Albert Shanker. (2000). Institute Preschool Curriculum: What's In It For Children And Teacher. Washington, DC: 555 New Jersey Avenue

Uno, Hamzah B. (2008). Profesi Kependidikan. Jakarta: Bumi Aksara. 